\title{
Diverse electron sources support denitrification under hypoxia in the obligate methanotroph Methylomicrobium album strain BG8
}

\author{
K. Dimitri Kits, Dustin J. Campbell, Albert R. Rosana and Lisa Y. Stein* \\ Department of Biological Sciences, Faculty of Science, University of Alberta, Edmonton, AB, Canada
}

OPEN ACCESS

Edited by:

Colin Murrell,

University of East Anglia, UK

Reviewed by:

Marina G. Kalyuzhanaya, San Diego State University, USA Adrian $\mathrm{Ho}$,

Netherlands Institute of Ecology, Netherlands

${ }^{*}$ Correspondence: Lisa Y. Stein Department of Biological Sciences, Faculty of Science, University of Alberta, CW 405, Biological Sciences Building, Edmonton, AB T6G 2E9, Canada lisa.stein@ualberta.ca

Specialty section: This article was submitted to Terrestrial Microbiology, a section of the journal

Frontiers in Microbiology

Received: 13 August 2015 Accepted: 18 September 2015

Published: 06 October 2015

Citation:

Kits KD, Campbell DJ, Rosana AR and Stein LY (2015) Diverse electron sources support denitrification under hypoxia in the obligate methanotroph Methylomicrobium album strain BG8.

Front. Microbiol. 6:1072. doi: 10.3389/fmicb.2015.01072
Aerobic methane-oxidizing bacteria (MOB) are a diverse group of microorganisms that are ubiquitous in natural environments. Along with anaerobic MOB and archaea, aerobic methanotrophs are critical for attenuating emission of methane to the atmosphere. Clearly, nitrogen availability in the form of ammonium and nitrite have strong effects on methanotrophic activity and their natural community structures. Previous findings show that nitrite amendment inhibits the activity of some cultivated methanotrophs; however, the physiological pathways that allow some strains to transform nitrite, expression of gene inventories, as well as the electron sources that support this activity remain largely uncharacterized. Here we show that Methylomicrobium album strain BG8 utilizes methane, methanol, formaldehyde, formate, ethane, ethanol, and ammonia to support denitrification activity under hypoxia only in the presence of nitrite. We also demonstrate that transcript abundance of putative denitrification genes, nirS and one of two norB genes, increased in response to nitrite. Furthermore, we found that transcript abundance of $p x m A$, encoding the alpha subunit of a putative coppercontaining monooxygenase, increased in response to both nitrite and hypoxia. Our results suggest that expression of denitrification genes, found widely within genomes of aerobic methanotrophs, allow the coupling of substrate oxidation to the reduction of nitrogen oxide terminal electron acceptors under oxygen limitation. The present study expands current knowledge of the metabolic flexibility of methanotrophs by revealing that a diverse array of electron donors support nitrite reduction to nitrous oxide under hypoxia.

Keywords: methanotroph, nitrous oxide, denitrification, hypoxia, Methylomicrobium album BG8, methane monooxygenase, nitrite reduction

\section{Introduction}

Aerobic methane-oxidizing bacteria (MOB) form an important bridge between the global carbon and nitrogen cycles, a relationship impacted by the global use of nitrogenous fertilizers (Bodelier and Steenbergh, 2014). Ammonia $\left(\mathrm{NH}_{3}\right)$ and nitrate $\left(\mathrm{NO}_{3}{ }^{-}\right)$can stimulate the activity of methanotrophs by acting as a nitrogen source for growth and biomass production (Bodelier et al., 2000; Bodelier and Laanbroek, 2004). Further, some methanotrophs such as Methylomonas denitrificans utilize $\mathrm{NO}_{3}{ }^{-}$as an oxidant for respiration under hypoxia (Kits et al., 2015). 
Evidently, denitrification in aerobic methanotrophs functions to conserve energy during oxygen $\left(\mathrm{O}_{2}\right)$ limitation (Kits et al., 2015). Alternatively, $\mathrm{NH}_{3}$ and nitrite $\left(\mathrm{NO}_{2}{ }^{-}\right)$can act as significant inhibitors of methanotrophic bacteria (King and Schnell, 1994). $\mathrm{NH}_{3}$ is a competitive inhibitor of the methane monooxygenase enzyme and $\mathrm{NO}_{2}{ }^{-}$, produced by methanotrophs that can oxidize $\mathrm{NH}_{3}$ to $\mathrm{NO}_{2}{ }^{-}$, is a toxin with bacteriostatic properties that is known to inhibit the methanotroph formate dehydrogenase enzyme that is essential for the oxidation of formate to carbon dioxide (Dunfield and Knowles, 1995; Cammack et al., 1999; Nyerges et al., 2010).

In spite of the recent discovery that aerobic methanotrophs can denitrify, the energy sources, genetic modules, and environmental factors that govern denitrification in MOB are still poorly understood. $M$. denitrificans FJG1 respires $\mathrm{NO}_{3}{ }^{-}$using methane as an electron donor to conserve energy. However, it is not known whether $\mathrm{C}_{1}$ energy sources other than $\mathrm{CH}_{4}$ (methanol, formaldehyde, and formate) can directly support denitrification. Another possibility, which has not yet been investigated, is that $\mathrm{C}_{2}$ compounds (such as ethane and ethanol) and inorganic reduced nitrogen sources $\left(\mathrm{NH}_{3}\right)$ support methanotrophic denitrification. Previous work shows that several obligate methanotrophs, including Methylomicrobium album strain BG8, oxidize ethane $\left(\mathrm{C}_{2} \mathrm{H}_{6}\right)$ and ethanol $\left(\mathrm{C}_{2} \mathrm{H}_{6} \mathrm{O}\right)$ using particulate methane monooxygenase (pMMO) and methanol dehydrogenase $(\mathrm{MDH})$, respectively, even though neither substrate supports growth (Whittenbury et al., 1970; Dalton, 1980; Mountfort, 1990). $\mathrm{NH}_{3}$ may be able to support methanotrophic denitrification because many aerobic methanotrophs are capable of oxidizing $\mathrm{NH}_{3}$ to $\mathrm{NO}_{2}{ }^{-}$: a process facilitated by the presence of a coppercontaining monooxygenase (CuMMO) enzyme and, in some methanotrophs, a hydroxylamine dehydrogenase homolog (Poret-Peterson et al., 2008). The ability to utilize alternative energy sources to support denitrification would augment the metabolic flexibility of methanotrophs and enable them to sustain respiration in the absence of $\mathrm{CH}_{4}$ and/or $\mathrm{O}_{2}$.

Methylomicrobium album strain BG8 is an aerobic methanotroph that belongs to the phylum Gammaproteobacteria; the genome lacks a soluble methane monooxygenase but does contain one particulate methane monooxygenase operon (pmoCAB - METAL_RS17430, 17425, 17420) and one operon encoding a putative copper monooxygenase (pxmABC - METAL_RS06980, 06975, 06970) with no known function. The genome also contains gene modules for import and assimilation of $\mathrm{NH}_{4}{ }^{+}$(amtB - METAL_RS11045/ $g d h B$ - METAL_RS11695/glnA - METAL_RS11070/ald METAL_RS11565), assimilation of $\mathrm{NO}_{3}^{-}$(nasA - METAL_ RS06040/nirB - METAL_RS15330, nirD - METAL_RS15325), oxidation of $\mathrm{NH}_{2} \mathrm{OH}$ to $\mathrm{NO}_{2}^{-}$(haoA - METAL_RS13275), as well as putative denitrification genes - cytochrome $c d_{1}$ nitrite reductase (nirS - METAL_RS10995), and two copies of cytochrome $c$-dependent nitric oxide reductase (norB1 METAL_RS03925, norC1 - METAL_RS03930/norB2 - METAL_ RS13345). The recent release of several genome sequences of aerobic methanotrophs, including M. album strain BG8, points to the frequent presence of putative nitrite and nitric oxide reductases, while only three cultivated methanotrophs possess a respiratory nitrate reductase (Stein and Klotz, 2011; Stein et al., 2011; Svenning et al., 2011; Khadem et al., 2012b; Vuilleumier et al., 2012; Kits et al., 2013). It is also unclear whether methanotrophs that lack a respiratory nitrate reductase but possess dissimilatory nitrite and nitric oxide reductases are still capable of denitrification from $\mathrm{NO}_{2}{ }^{-}$. Moreover, due to the significant divergence of the methanotroph nirS from known sequences, it is not known, whether nirS is the operational nitrite reductase in the methanotrophs that lack a nirK (Wei et al., 2015). While the genome of the nitrate respiring $M$. denitrificans FJG1 encodes both nirS and nirK nitrite reductases, transcript levels of only nirK increased in response to denitrifying conditions (Kits et al., 2015).

The goal of the present study was to test whether a variety of $\mathrm{C}_{1}, \mathrm{C}_{2}$, and inorganic energy sources can directly support denitrification, characterize the environmental factors that regulate $\mathrm{NO}_{2}{ }^{-}$-dependent $\mathrm{N}_{2} \mathrm{O}$ production in $M$. album strain BG8 and to assess the expression of its putative denitrification inventory.

\section{Materials and Methods}

\section{Cultivation}

Methylomicrobium album strain BG8 was cultivated in $100 \mathrm{~mL}$ of nitrate mineral salts medium containing $11 \mathrm{mM} \mathrm{KNO}_{3}$ (NMS) or $10 \mathrm{mM} \mathrm{KNO}_{3}$ plus $1 \mathrm{mM} \mathrm{NaNO} 2\left(\mathrm{NMS}+\mathrm{NO}_{2}{ }^{-}\right.$) in $300 \mathrm{~mL}$ glass Wheaton bottles topped with butyl rubber septa (Whittenbury et al., 1970). The NMS media was buffered to pH 6.8 using a phosphate buffer $\left(0.26 \mathrm{~g} / \mathrm{L} \mathrm{KH}_{2} \mathrm{PO}_{4}, 0.33 \mathrm{~g} / \mathrm{L}\right.$ $\left.\mathrm{Na}_{2} \mathrm{HPO}_{4}\right)$. The final concentration of copper $\left(\mathrm{CuSO}_{4}\right)$ was $5 \mu \mathrm{M}$. Using a $60 \mathrm{~mL}$ syringe (BD) and a $0.22 \mu \mathrm{m}$ filter/needle assembly, $\mathrm{CH}_{4}(99.998 \%)$ was added into the sealed bottles as a sole carbon source. The initial gas-mixing ratio in the headspace was adjusted using $\mathrm{O}_{2}$ gas $\left(99.998 \%\right.$, Praxair) to $1.6: 1, \mathrm{CH}_{4}$ to $\mathrm{O}_{2}$ (or ca. $28 \% \mathrm{CH}_{4}, 21 \% \mathrm{O}_{2}$ ). The initial pressure in the gas tight bottles was adjusted to ca. 1.3 atm to prevent a vacuum from forming during growth as gas samples and liquid culture samples were withdrawn every $12 \mathrm{~h}$ for analysis. Cultures were incubated at $30^{\circ} \mathrm{C}$ and shaken at $200 \mathrm{rpm}$. To track growth, the cultures were periodically sampled using a needle fitted syringe $(0.5 \mathrm{~mL})$ and cell density was determined by direct count with phase contrast microscopy using a Petroff-Hausser counting chamber. Six biological replicates were grown on separate days and data was collected on each replicate $(n=6)$. Culture purity was assessed by $16 \mathrm{~s}$ rRNA gene sequencing, phase contrast microscopy, and plating on nutrient agar and TSA with absence of growth indicating no contamination. We assessed purity of the cultures prior to beginning all of the experiments and then assessed it again for each replicate at the conclusion of each experiment.

\section{Gas Analysis}

Concentrations of $\mathrm{O}_{2}, \mathrm{CH}_{4}$, and $\mathrm{N}_{2} \mathrm{O}$ were determined by sampling the headspace of each culture using gas chromatography (GC-TCD, Shimadzu GC8A; outfitted with 
a molecular sieve 5A and a Hayesep Q column, Alltech). The headspace of each batch culture was sampled with a $250 \mu \mathrm{L}$ gastight syringe (SGE Analytical Science; $100 \mu \mathrm{L} /$ injection) at 0 (immediately post inoculation), $6,12,16,20,24,30,36,42$, $48,60,72,96$, and $120 \mathrm{~h}$. A total of $200 \mu \mathrm{L}$ was sampled from each replicate at every time point. We determined the bottles were gastight by leaving a replicate set of bottles uninoculated throughout the experiment and measuring headspace gas concentrations; leakage was $<1 \%$ over $120 \mathrm{~h}$. Standard curves using pure gases $\mathrm{O}_{2}, \mathrm{CH}_{4}$, and $\mathrm{N}_{2} \mathrm{O}$ (Praxair) were generated and used to calculate the headspace concentrations in the batch cultures.

\section{Instantaneous Micro-sensor Assays}

Methylomicrobium album strain BG8 was grown in $\mathrm{NMS}+\mathrm{NO}_{2}^{-}$medium as described above. At $96 \mathrm{~h}$ of growth, when denitrification activity was highly evident, $4 \times 10^{10}$ cells were harvested using a filtration manifold onto $0.2 \mu \mathrm{m}$ filters (Supor 200, $47 \mathrm{~mm}$, Pall Corporation). The biomass was washed three times with sterile, nitrogenfree mineral salts medium - identical to the mineral salts medium used for cultivation but devoid of $\mathrm{NH}_{4} \mathrm{Cl}$, $\mathrm{KNO}_{3}$, or $\mathrm{NaNO}_{2}$. For data presented in Figures 2 and 4, the washed biomass was resuspended in the same nitrogen-free medium and transferred to a gastight $10 \mathrm{~mL}$ micro-respiration chamber equipped with an OX-MR $\mathrm{O}_{2}$ micro-sensor (Unisense) and an $\mathrm{N}_{2} \mathrm{O}-500 \mathrm{~N}_{2} \mathrm{O}$ micro-sensor (Unisense). For data presented in Figure 3, biomass was resuspended in mineral salts medium amended with $100 \mu \mathrm{M}$ $\mathrm{NaNO}_{2}$. Data was logged using SensorTrace Basic software. $\mathrm{CH}_{4}$ gas, $0.001 \% \mathrm{CH}_{3} \mathrm{OH}$ (HPLC grade methanol, Fisher Scientific), $0.01 \% \mathrm{CH}_{2} \mathrm{O}$ (Methanol free $16 \%$ formaldehyde, Life technologies), $10 \mathrm{mM} \mathrm{HCO}_{2} \mathrm{H}, \mathrm{C}_{2} \mathrm{H}_{6}$ gas (99.999\%), $0.01 \% \mathrm{C}_{2} \mathrm{H}_{6} \mathrm{O}$ (Methanol free 95\% ethyl alcohol, Commercial Alcohols), $200 \mathrm{mM} \mathrm{NH}_{4} \mathrm{Cl}$, and/or $1 \mathrm{M} \mathrm{NO}_{2}{ }^{-}$was injected directly into the chamber through the needle injection port with a gas-tight syringe (SGE Analytical Science). In Figures 3B-E, the dissolved $\mathrm{O}_{2}$ was decreased to $<100 \mu \mathrm{mol} / \mathrm{L}$
(Figure 3B) and $<25 \mu \mathrm{mol} / \mathrm{L}$ (Figures 3C-E), respectively, with additions of $\mathrm{CH}_{4}$ (Figure 3A), $\mathrm{CH}_{3} \mathrm{OH}$ (Figure 3B), $\mathrm{CH}_{2} \mathrm{O}$ (Figure 3C), $\mathrm{HCO}_{2} \mathrm{H}$ (Figure 3D), $\mathrm{C}_{2} \mathrm{H}_{6}$ (Figure 3E), $\mathrm{C}_{2} \mathrm{H}_{6} \mathrm{O}$ (Figure 3F) before data logging was enabled to limit the traces to $<100 \mathrm{~min}$ and to reduce the number of sampling points. $\mathrm{NO}_{2}^{-}$concentration was determined using a colorimetric method (Bollmann et al., 2011). Experiments were performed 3-4 times to demonstrate reproducibility of results and a single representative experiment was selected for presentation.

\section{RNA Extraction}

Total RNA was extracted from ca. $10^{9}$ M. album strain BG8 cells grown in NMS or NMS $+\mathrm{NO}_{2}{ }^{-}$medium at 24, 48, and $72 \mathrm{~h}$ using the MasterPure RNA purification kit (Epicentre). Briefly, cells were harvested by filtration through a $0.22 \mu \mathrm{m}$ filter and inactivated with phenol-ethanol stop solution (5\% phenol, 95\% EtOH). Total nucleic acid was purified according to manufacturer's instructions with the following modifications: $6 \mathrm{U}$ proteinase $\mathrm{K}$ (Qiagen) were added to the cell lysis step and the total precipitated nucleic acid was treated with 30 units of DNase I (Ambion). The total RNA was then columnpurified using RNA clean \& concentrator (Zymo Research). RNA quality and quantity was assessed using BioAnalyzer (Agilent Technologies) and Qubit (Life Technologies). Residual genomic DNA contamination was assessed by quantitative PCR (qPCR) targeting norB1 or nirS genes (primers listed in Table 1). PCR conditions are described below. The total RNA samples were deemed free of genomic DNA if no amplification was detected after 40 cycles of qPCR. High quality RNA (RIN number $>9$, no gDNA detected) was converted to first strand cDNA using Superscript III reverse transcriptase (Life Technologies), according to manufacturer's instructions.

\section{Quantitiative PCR}

Gene copy standards were created using the genomic DNA of M. album strain BG8 using universal and gene-specific primers

\begin{tabular}{|c|c|c|c|c|c|c|}
\hline pxmA & METAL_RS06980 & QpxmA-FWD-3 & GCTTGTCAGGGCTTACGATTA & $97.7 \%-101.8 \%$ & 0.9989 & This study \\
\hline \multirow[t]{2}{*}{ pmoA } & METAL_RS17425 & QpmoA-FWD-7 & GTTCAAGCAGTTGTGTGGTATC & $95.1 \%-97.2 \%$ & 0.9999 & This study \\
\hline & & QpmoA-REV-7 & GAATTGTGATGGGAACACGAAG & & & \\
\hline \multirow[t]{2}{*}{ norB1 } & METAL_RS03925 & QnorB-FWD-2 & ACTGGCGGTGCACTATTT & $97.2 \%-97.4 \%$ & 0.9998 & This study \\
\hline & & QnorB-REV-2 & CATCCGGTTGACGTTGAAATC & & & \\
\hline \multirow[t]{2}{*}{ norB2 } & METAL_RS13345 & QnorB-F-1 & CACCATGTACACCCTCATCTG & $96.2 \%-102.2 \%$ & 0.9999 & This study \\
\hline & & QnorB-R-1 & CCAAAGTCTGCGCAAGAAAC & $96.1 \%-101.8 \%$ & 0.9999 & This study \\
\hline $16 \mathrm{~S}$ rRNA & METAL_RS04240 & $341 \mathrm{~F}$ & CCTACGGGAGGCAGCAG & $96.9 \%-102.2 \%$ & 0.9997 & Muyzer et al., 1993 \\
\hline
\end{tabular}

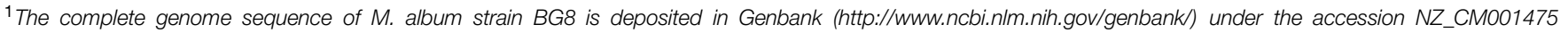
(http://www.ncbi.nlm.nih.gov/genome/?term=methylomicrobium\%20album\%20Bg8). 
(Table 1). A 10 -fold dilution series $\left(10^{0}-10^{8}\right.$ copies $/ 20 \mu \mathrm{l}$ reaction) of purified amplicons was prepared and used to establish an optimized $\mathrm{qPCR}$ condition. Each $20 \mu \mathrm{l}$ reaction contained $10 \mu \mathrm{l}$ of $2 \mathrm{X}$ qPCR SYBR based master mix (MBSU, University of Alberta), $0.2 \mu \mathrm{M}$ of forward and reverse primer, $1 \mu \mathrm{l}$ diluted cDNA, and nuclease-free water. Amplification was performed on a StepOne Plus qPCR system (Applied Biosystems) with an initial activation at $95^{\circ} \mathrm{C}$ for $3 \mathrm{~min}$ and fluorescence emission data collected from 40 cycles of amplification $\left(95^{\circ} \mathrm{C}\right.$ for $15 \mathrm{~s}, 60^{\circ} \mathrm{C}$ for $15 \mathrm{~s}$, and $72^{\circ} \mathrm{C}$ for $15 \mathrm{~s}$ ). Target specificity was assessed by melt curve analysis, which ensured that a single peak was obtained. Gene copy number was estimated from cDNA diluted from $10^{-3}$ to $10^{-5}$ copies for $16 \mathrm{~S}$ rRNA and $p m o A$ transcript analyses and dilutions from $10^{-1}$ to $10^{-3}$ copies for nirS, norB1, norB2, and pxmA transcript analyses. The transcript abundance of each functional gene was normalized to that of $16 \mathrm{~s}$ rRNA to yield a copy number of transcripts per one billion copies of $16 \mathrm{~s}$ rRNA. Then, to calculate the $\mathrm{N}$-fold change, we divided the transcript abundance (per one billion copies of 16s rRNA) in the NMS $+\mathrm{NO}_{2}{ }^{-}$cultures by transcript abundance (per one billion copies of 16s rRNA) in the NMS cultures. Samples were run in triplicate with three dilutions each on at least three biological replicates from cells grown and processed on separate dates. Quantitative PCR efficiencies ranged from $95-102 \%$ with $r^{2}$-values of at least 0.99 for all assays (Table 1).

\section{Statistics}

A Student's $t$-test (two tailed) was used to calculate the P-level between the control (NMS alone) and experimental (NMS $+\mathrm{NO}_{2}^{-}$) replicates as indicated for each experiment. Equal variance between the control and experimental groups was determined using a two sample $F$ test for variance. The doubling time, $\mathrm{O}_{2}$ and $\mathrm{CH}_{4}$ consumption, cell density, and total headspace $\mathrm{O}_{2}$ and $\mathrm{CH}_{4}$ consumed (Supplementary Table S1) all had equal variance between the control and experimental $\left(F<F_{\text {crit }}\right)$; thus a homoscedastic $t$-test was calculated for the aforementioned comparisons. For qPCR, comparisons between NMS $+\mathrm{NO}_{2}{ }^{-}$and NMS alone at $48 \mathrm{~h}$ for $p m o A$, pxmA, nirS, and norB1, as well as for pxmA and nirS at $72 \mathrm{~h}$ showed unequal variance $\left(F>F_{\text {crit }}\right)$; thus a heteroscedastic $t$-test was used to calculate the P-level for these comparisons. The variance between $\mathrm{NMS}+\mathrm{NO}_{2}^{-}$and NMS alone for all other genes at all other time points was equal $\left(F<F_{\text {crit }}\right)$.

\section{Results}

\section{Growth Phenotype of Methylomicrobium album Strain BG8 in the Absence or Presence of $\mathrm{NO}_{2}^{-}$}

Methylomicrobium album strain BG8 was cultivated in NMS or NMS supplemented with $\mathrm{NO}_{2}{ }^{-}$over $120 \mathrm{~h}$ to determine the effect of $\mathrm{NO}_{2}{ }^{-}$on growth, $\mathrm{O}_{2}$ and $\mathrm{CH}_{4}$ consumption, and $\mathrm{N}_{2} \mathrm{O}$ production (Figure 1 ). The total amount of nitrogen was kept constant to eliminate a difference in $\mathrm{N}$-availability and salt concentration between treatments. All of the cultures were initiated at an oxygen $\left(\mathrm{O}_{2}\right)$ tension of $19.5 \pm 0.7 \%$ (Figure 1B). As observed previously (Nyerges et al., 2010), $\mathrm{NO}_{2}{ }^{-}$ amendment $(1 \mathrm{mM})$ did not have an inhibitory effect on growth or substrate consumption of M. album strain BG8 (Figures 1A-C and Supplementary Table S1). The limiting substrate in all treatments was $\mathrm{O}_{2}$, as demonstrated by supplementing cultures with additional $\mathrm{O}_{2}(20 \mathrm{~mL})$ after $48 \mathrm{~h}$ of growth and observing a significant increase in optical density in comparison to cultures not receiving additional $\mathrm{O}_{2}$ (Supplementary Figure $\mathrm{S} 1$ ). $\mathrm{N}_{2} \mathrm{O}$ production occurred only in the NMS plus $\mathrm{NO}_{2}{ }^{-}$cultures (Figure 1D). $\mathrm{N}_{2} \mathrm{O}$ production was first apparent in the headspace of $\mathrm{NO}_{2}{ }^{-}$amended cultures at $72 \mathrm{~h}$ of growth when $\mathrm{O}_{2}$ reached ca. $1.8 \%$ of the headspace and continued up to the termination of the experiment $(120 \mathrm{~h})$ at a rate of $9.3 \times 10^{-18} \mathrm{~mol}$ $\mathrm{N}_{2} \mathrm{O}$ per cell per hour (Figure 1D). After $120 \mathrm{~h}$ of growth, the $\mathrm{N}_{2} \mathrm{O}$ yield percentage from the added $\mathrm{NO}_{2}^{-}(100 \mu \mathrm{mol})$ was $5.1 \pm 0.2 \%(5.1 \pm 0.2 \mu \mathrm{mol})$ in the $\mathrm{NMS}+\mathrm{NO}_{2}{ }^{-}$ cultures.

\section{$\mathrm{O}_{2}$ Consumption and $\mathrm{N}_{2} \mathrm{O}$ Production by Resting Cells of $M$. album Strain BG8 with Single or Double Carbon Substrates or Ammonium under Atmospheric and Hypoxic $\mathrm{O}_{2}$ Tensions}

To determine which conditions govern $\mathrm{N}_{2} \mathrm{O}$ production in $M$. album strain BG8, we measured instantaneous $\mathrm{O}_{2}$ consumption and $\mathrm{N}_{2} \mathrm{O}$ production by $M$. album strain BG8 with $\mathrm{CH}_{4}$ as the sole carbon and energy source in a closed $10-\mathrm{mL}$ micro-respiratory (MR) chamber outfitted with $\mathrm{O}_{2}$ and $\mathrm{N}_{2} \mathrm{O}$ detecting microsensors. Introduction of $\mathrm{CH}_{4}(300 \mu \mathrm{M})$ into the chamber led to immediate $\mathrm{O}_{2}$ consumption; $\mathrm{O}_{2}$ declined to below the detection limit of the sensor $\left(<50 \mathrm{nM} \mathrm{O}_{2}\right)$ after ca. 3 min (Figure 2A). Addition of $\mathrm{NO}_{2}{ }^{-}$to the chamber led to production of $\mathrm{N}_{2} \mathrm{O}$ shortly after $\mathrm{O}_{2}$ declined below the detection limit at a rate of $7.9 \times 10^{-18} \mathrm{~mol} \mathrm{cell}^{-1} \mathrm{~h}^{-1}$ (Figure $2 \mathrm{~B}$ ). In the absence of $\mathrm{NO}_{2}{ }^{-}$, we observed no measureable $\mathrm{N}_{2} \mathrm{O}$ production (Figure 2A). Though the $\mathrm{O}_{2}$ concentration is $<50 \mathrm{nM} \mathrm{O}$ when $\mathrm{N}_{2} \mathrm{O}$ production is evident, it is important to note that $M$. album strain BG8 still requires $\mathrm{O}_{2}$ for methane oxidation and cannot grow on $\mathrm{CH}_{4}$ anaerobically.

Using the same setup described above, we supplemented resting cells in the MR chamber with $\mathrm{CH}_{3} \mathrm{OH}, \mathrm{CH}_{2} \mathrm{O}, \mathrm{HCO}_{2} \mathrm{H}$, $\mathrm{C}_{2} \mathrm{H}_{6}$, or $\mathrm{C}_{2} \mathrm{H}_{6} \mathrm{O}$ to experimentally address whether carbonbased reductant sources other than $\mathrm{CH}_{4}$ support denitrification in $M$. album strain BG8. Also, to substantiate that the one- and two-carbon sources we tested can all serve as direct electron donors for denitrification by $M$. album strain BG8 under hypoxia, we provided resting cells only enough reductant to consume the dissolved $\mathrm{O}_{2}$ (ca. $234 \mu \mathrm{mol} / \mathrm{L}$ ) present in the MR chamber sparing no reductant to support denitrification (Figure 3). We then measured instantaneous $\mathrm{N}_{2} \mathrm{O}$ production through serial addition of small quantities of $\mathrm{CH}_{4}, \mathrm{CH}_{3} \mathrm{OH}, \mathrm{CH}_{2} \mathrm{O}, \mathrm{HCO}_{2} \mathrm{H}, \mathrm{C}_{2} \mathrm{H}_{6}$, or $\mathrm{C}_{2} \mathrm{H}_{6} \mathrm{O}$ to the $\mathrm{MR}$ chamber, which contained medium supplemented with $\mathrm{NaNO}_{2}\left(100 \mu \mathrm{M}\right.$; Figure 3). For all six substrates, $\mathrm{N}_{2} \mathrm{O}$ 

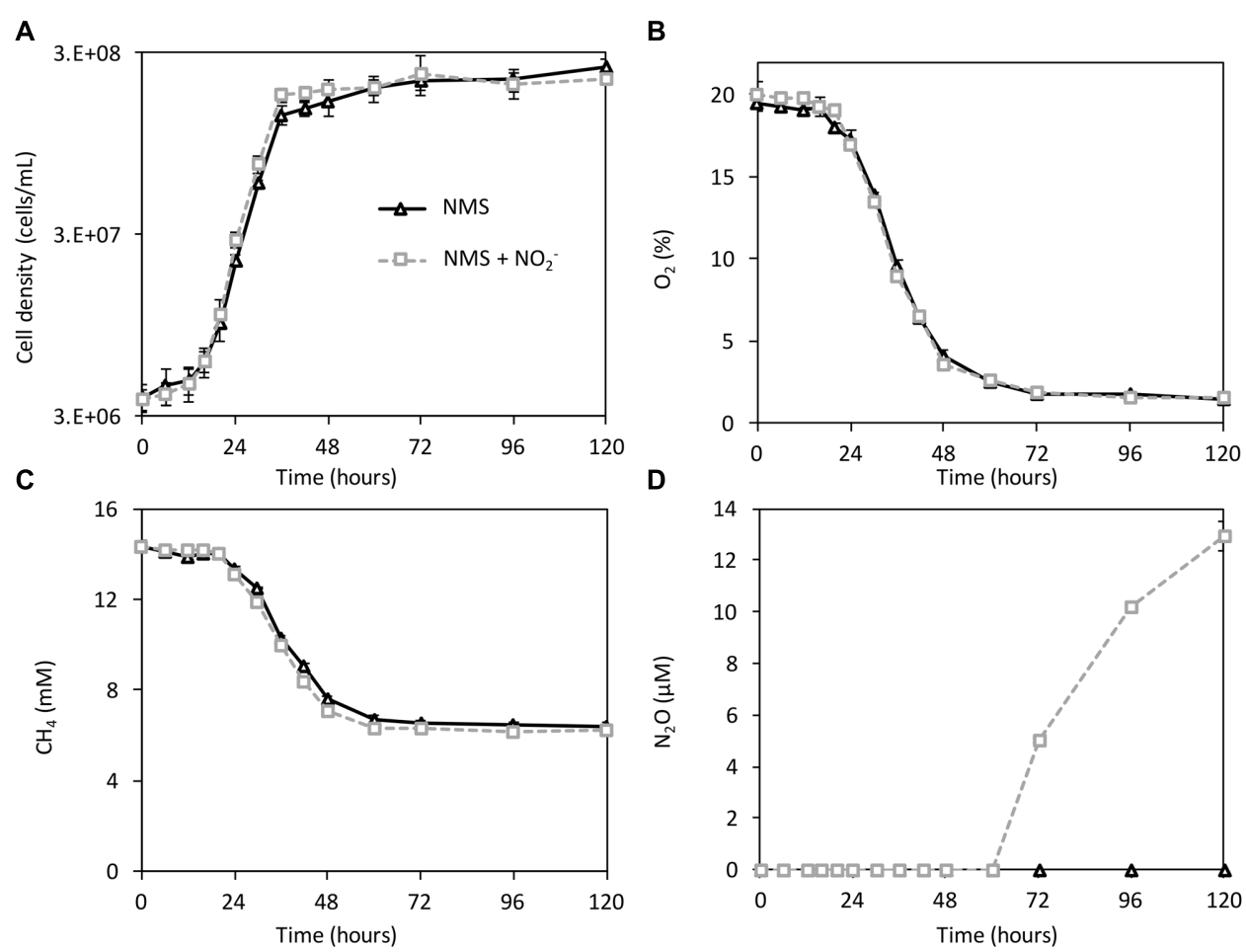

FIGURE 1 | Growth, $\mathrm{CH}_{4}$ and $\mathrm{O}_{2}$ consumption, and $\mathrm{N}_{2} \mathrm{O}$ production by Methylomicrobium album strain BG8 cultivated on NMS and NMS plus 1 mM $\mathrm{NaNO}_{2}$. Methylomicrobium album strain BG8 was cultivated for 5 days in $100 \mathrm{~mL}$ of NMS (black triangles) or NMS $+1 \mathrm{mM} \mathrm{NO}_{2}^{-}$(gray dashed squares) media in $300 \mathrm{~mL}$ closed glass Wheaton bottles sealed with butyl rubber septum caps. The initial headspace gas-mixing ratio of $\mathrm{CH}_{4}$ to $\mathrm{O}_{2}$ was 1.6:1. Cell density (A) was measured using direct count with a Petroff-Hausser counting chamber and headspace gas concentrations of $\mathrm{O}_{2}$ (B), $\mathrm{CH}_{4}$ (C) and $\mathrm{N}_{2} \mathrm{O}$ (D) were measured using GC-TCD. All data points represent the mean \pm SD for six biological replicates $(n=6)$.

production was stoichiometric with the amount of added substrate (Figure 3).

Many methanotrophs, including $M$. album BG8, can oxidize $\mathrm{NH}_{3}$ to $\mathrm{NO}_{2}{ }^{-}$due to homologous inventory to ammoniaoxidizing bacteria (Yoshinari, 1985; Bedard and Knowles, 1989; King and Schnell, 1994; Holmes et al., 1995; Poret-Peterson et al., 2008; Campbell et al., 2011; Stein and Klotz, 2011). We aimed to test whether reductant and $\mathrm{NO}_{2}{ }^{-}$from $\mathrm{NH}_{3}$ oxidation could also drive denitrification by $M$. album strain BG8. Resting cells in the MR chamber consumed the dissolved $\mathrm{O}_{2}$ promptly after $\mathrm{NH}_{4} \mathrm{Cl}(200 \mu \mathrm{M})$ was injected into the chamber (Figure 4). After ca. $70 \mathrm{~min}$, the biomass depleted the dissolved $\mathrm{O}_{2}$ to $<50 \mathrm{nM}$ and $\mathrm{NO}_{2}{ }^{-}$concentration reached $163 \pm 5 \mu \mathrm{M}$. The rate of $\mathrm{N}_{2} \mathrm{O}$ production following $\mathrm{O}_{2}$ depletion was $1.2 \times 10^{-18} \mathrm{~mol} \mathrm{cell}^{-1} \mathrm{~h}^{-1}$.

\section{Expression of Predicted Denitrification Genes in M. album Strain BG8 under Denitrifying Conditions}

The genome of $M$. album strain BG8 encodes several genes predicted to be involved in denitrification. The first step in respiratory denitrification is the one-electron reduction of $\mathrm{NO}_{3}^{-}$to $\mathrm{NO}_{2}^{-}$; a reaction performed by one of two membrane-associated dissimilatory nitrate reductase enzymes, neither of which is encoded in the M. album strain BG8 genome (Kits et al., 2013). The second step in denitrification, the one-electron reduction of $\mathrm{NO}_{2}{ }^{-}$to $\mathrm{NO}$ is carried out by one of two non-homologous nitrite reductases, either a copper containing (nirK) or a cytochrome $\mathrm{cd}_{1}$ containing (nirS) nitrite reductase, of which the latter was annotated in the genome (Kits et al., 2013). The genome of $M$. album strain BG8 also contains two copies of a putative cytochrome $c$-dependent nitric oxide reductase (norB1 and norB2, respectively). We also investigated expression of the pxmA gene of the pxmABC operon that encodes a CuMMO with evolutionarily relatedness to particulate methane monooxygenase (Tavormina et al., 2011). We chose to examine expression of pxmA in $M$. album strain BG8 to determine whether this gene responded similarly to that of $M$. denitrificans FJG1; expression of the pxmABC operon in $M$. denitrificans FJG1 significantly increased in response to denitrifying conditions (Kits et al., 2015).

To assess the effect of $\mathrm{NO}_{2}{ }^{-}$amendment on gene expression, we used cultures grown in NMS alone as the control. The $\mathrm{O}_{2}$ concentration in the headspace of NMS and $\mathrm{NMS}+\mathrm{NO}_{2}{ }^{-}$ cultures after $24 \mathrm{~h}$ growth was ca. 17.2 and $16.9 \%$, respectively (Figure 1B). The transcript levels of $p m o A, p x m A$, nirS, and norB1 were significantly higher at the 24 and $48 \mathrm{~h}$ time points in the $\mathrm{NO}_{2}{ }^{-}$amended cultures when compared to the 

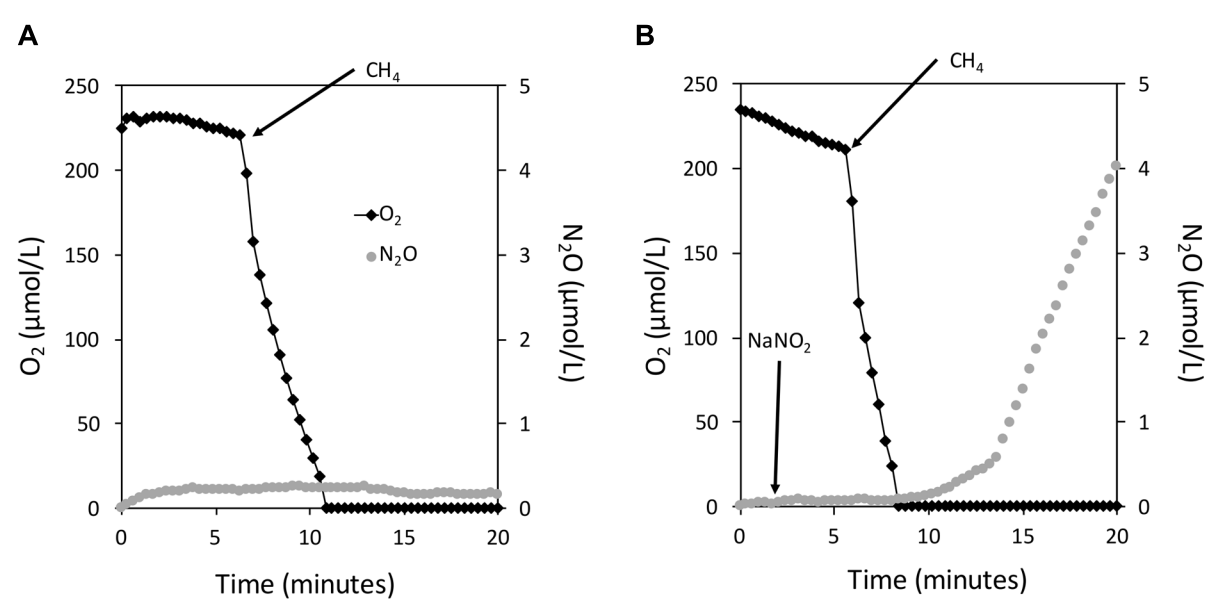

FIGURE 2 | The instantaneous coupling of $\mathrm{CH}_{\mathbf{4}}$ oxidation to $\mathrm{NO}_{2}{ }^{-}$reduction in Methylomicrobium album strain $\mathrm{BG} 8$ under hypoxia. Experiments were performed in a closed $10 \mathrm{~mL}$ micro-respiratory chamber outfitted with an $\mathrm{O}_{2}$ and $\mathrm{N}_{2} \mathrm{O}$ microsensor and logged with Sensor Trace Basic software. $\mathrm{O}_{2}$ (black

diamonds) and $\mathrm{N}_{2} \mathrm{O}$ (gray circles) were measured using microsensors. Cells of $M$. album strain BG8 were harvested as described in the materials and methods and resuspended in nitrogen free mineral salts medium. Arrows mark the addition of $\mathrm{CH}_{4}(\sim 300 \mu \mathrm{M})$ and $\mathrm{NaNO}_{2}(1 \mathrm{mM})$ to the micro-respiratory chamber in all panels.

There is no measureable denitrification activity in the absence of $\mathrm{NO}_{2}{ }^{-} \mathbf{( A )}$; denitrification activity is dependent on $\mathrm{CH}_{4}$ and $\mathrm{NO}_{2}{ }^{-}(\mathbf{B})$.

NMS alone (Figure 5). At the $72 \mathrm{~h}$ time point, levels of pmoA and nirS transcript levels remained significantly elevated in the $\mathrm{NMS}+\mathrm{NO}_{2}^{-}$relative to the NMS only cultures, whereas expression of norB1 was no longer significantly elevated (Figure 5). Most interestingly, the transcript abundance of pxmA at $72 \mathrm{~h}$ was 19.8 -fold higher in $\mathrm{NMS}+\mathrm{NO}_{2}{ }^{-}$relative to NMS only cultures (Figure 5). The second copy of norB (norB2) was unresponsive (below twofold) to $\mathrm{NO}_{2}{ }^{-}$amendment at all time points sampled.

\section{Discussion}

\section{Methylomicrobium album Strain BG8 Produces $\mathrm{N}_{2} \mathrm{O}$ Only as a Function of Hypoxia and $\mathrm{NO}_{2}{ }^{-}$}

Batch cultivation of $M$. album BG8 clearly revealed that both $\mathrm{NO}_{2}{ }^{-}$and low $\mathrm{O}_{2}$ were required for denitrification, as measured by $\mathrm{N}_{2} \mathrm{O}$ production. Although batch cultures of $M$. album strain BG8 have been shown to produce $\mathrm{N}_{2} \mathrm{O}$ previously in end-point assays (Nyerges et al., 2010), the mechanism and required conditions for denitrification by this strain were not determined until now. $\mathrm{N}_{2} \mathrm{O}$ production by $M$. denitrificans FJG1 was also shown to be dependent on hypoxia (Kits et al., 2015); however, this strain was able to respire $\mathrm{NO}_{3}{ }^{-}$in addition to $\mathrm{NO}_{2}{ }^{-}$likely due to the presence of a narGHJI dissimilatory nitrate reductase that is absent in the genome of $M$. album strain BG8. The genome of $M$. album strain BG8 encodes putative dissimilatory nitrite (nirS) and nitric oxide (norB) reductases (Kits et al., 2013) like $M$. denitrificans FJG1; hence, it is likely that $\mathrm{N}_{2} \mathrm{O}$ by $M$. album strain $\mathrm{BG} 8$ is from the enzymatic reduction of $\mathrm{NO}_{2}{ }^{-}$to $\mathrm{N}_{2} \mathrm{O}$ via the intermediate NO.

The correlation between $\mathrm{N}_{2} \mathrm{O}$ production and low $\mathrm{O}_{2}$ tension is similar to two other microbial processes, aerobic denitrification in heterotrophic bacteria such as Paracoccus denitrificans and nitrifier denitrification in ammonia-oxidizing bacteria (Richardson et al., 2001; Kozlowski et al., 2014). Aerobic denitrification in chemoorganoheterotrophs and nitrifier-denitrification in ammonia-oxidizing bacteria is a tactic used to maximize respiration during $\mathrm{O}_{2}$ limitation or to expend surplus reductant (Richardson et al., 2001; Stein, 2011). Utilization of $\mathrm{NO}_{2}{ }^{-}$in combination with or instead of $\mathrm{O}_{2}$ in the respiratory chain of $M$. album strain BG8 would reduce the overall cellular $\mathrm{O}_{2}$ demand, thus conserving $\mathrm{O}_{2}$ for additional $\mathrm{CH}_{4}$ oxidation. Thus, it is possible that M. album strain BG8 uses $\mathrm{NO}_{2}{ }^{-}$as a terminal electron acceptor under $\mathrm{O}_{2}$ limitation to maximize total respiration. The $\mathrm{N}_{2} \mathrm{O}$ yield percentage from $\mathrm{NO}_{2}{ }^{-}$by $M$. album strain BG8 $(5.1 \pm 0.2 \%)$ is similar to that of Nitrosomonas europaea ATCC 19718 (ca. 4.8\%) and one order of magnitude higher than that of Nitrosospira multiformis ATCC 25196 (0.27 \pm 0.05\%; Kozlowski et al., 2014; Stieglmeier et al., 2014).

\section{Denitrification by M. album Strain BG8 is Enzymatically Supported by Diverse Reductant Sources}

Resting cells of $M$. album strain BG8 reduced $\mathrm{NO}_{2}{ }^{-}$to $\mathrm{N}_{2} \mathrm{O}$ at the expense of any of four tested $\mathrm{C}_{1}$ substrates $\left(\mathrm{CH}_{4}\right.$, $\left.\mathrm{CH}_{3} \mathrm{OH}, \mathrm{CH}_{2} \mathrm{O}, \mathrm{HCO}_{2} \mathrm{H}\right)$, the two $\mathrm{C}_{2}$ substrates $\left(\mathrm{C}_{2} \mathrm{H}_{6}\right.$, $\mathrm{C}_{2} \mathrm{H}_{6} \mathrm{O}$ ), and $\mathrm{NH}_{4} \mathrm{Cl}$. These data show that intermediates of the methanotrophic pathway and co-substrates of pMMO, $\mathrm{MDH}$, and likely hydroxylamine dehydrogenase support respiratory denitrification. These results agree with previous work on the methanotroph Methylocystis sp. strain SC2, which couples $\mathrm{CH}_{3} \mathrm{OH}$ oxidation to denitrification under anoxia (Dam et al., 2013). Remarkably, both $\mathrm{C}_{2}$ compounds we tested $-\mathrm{C}_{2} \mathrm{H}_{6}$ and $\mathrm{C}_{2} \mathrm{H}_{6} \mathrm{O}$ - supported denitrification. The ability of $\mathrm{C}_{2}$ compounds to support denitrification in 
A

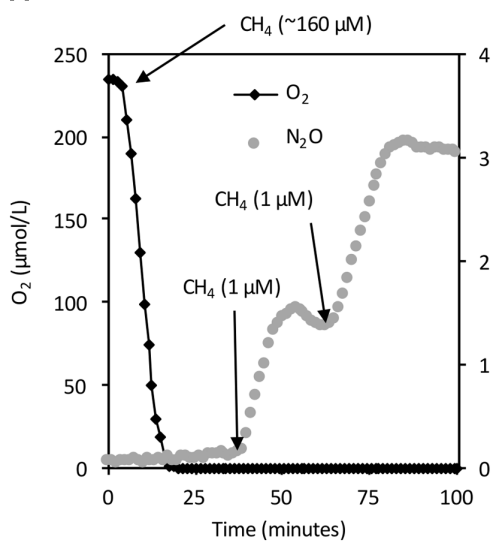

D

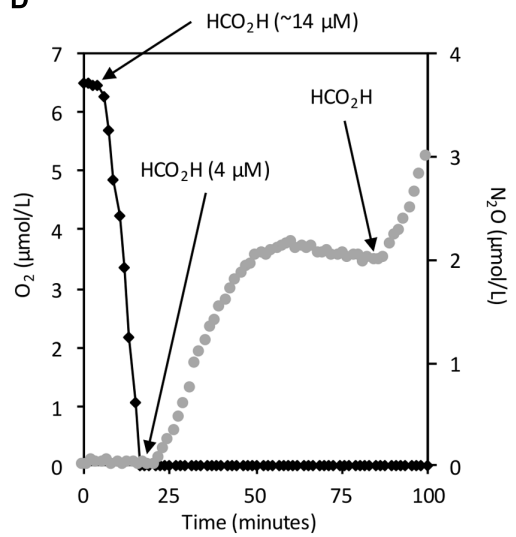

B

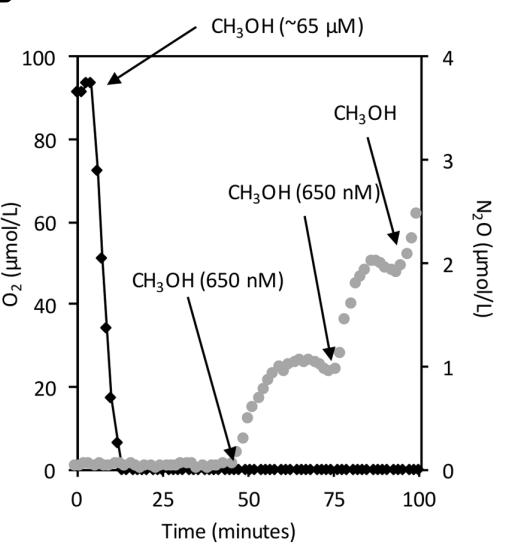

E

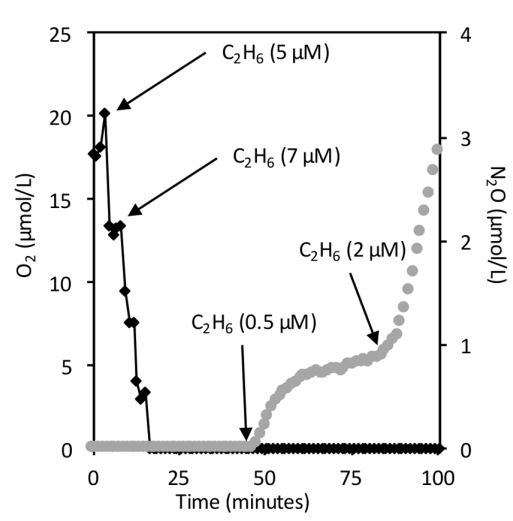

C

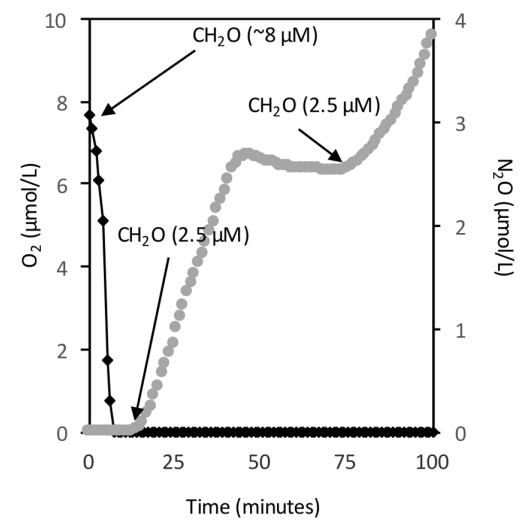

$\mathbf{F}$

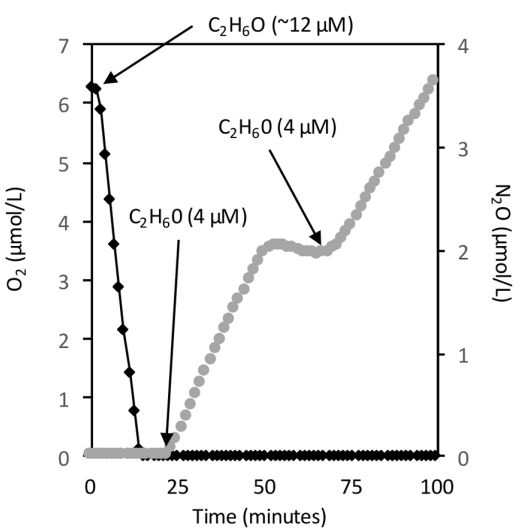

FIGURE $3 \mid \mathbf{N O}_{2}{ }^{-}$reduction to $\mathbf{N}_{\mathbf{2}} \mathbf{O}$ by $\mathbf{M}$. album strain $\mathbf{B G 8}$ is dependent on an energy source at $<\mathbf{5 0} \mathbf{n M} \mathbf{O}_{\mathbf{2}}$. Experiments were performed in a closed $10 \mathrm{~mL}$ micro-respiratory chamber outfitted with an $\mathrm{O}_{2}$ and $\mathrm{N}_{2} \mathrm{O}$ microsensor and logged with Sensor Trace Basic software. $\mathrm{O}_{2}$ (black diamonds) and $\mathrm{N}_{2} \mathrm{O}$ (gray circles). Cells of $M$. album strain BG8 were harvested as described in the materials and methods and resuspended in mineral salts medium containing $100 \mu \mathrm{M}$ $\mathrm{NO}_{2}{ }^{-}$. Arrows mark the addition of either $\mathrm{CH}_{4} \mathbf{( A )}, \mathrm{CH}_{3} \mathrm{OH}(\mathbf{B}), \mathrm{CH}_{2} \mathrm{O}(\mathbf{C}), \mathrm{HCO}_{2} \mathrm{H}(\mathbf{D}), \mathrm{C}_{2} \mathrm{H}_{6}(\mathbf{E}), \mathrm{C}_{2} \mathrm{H}_{6} \mathrm{O}(\mathbf{F})$, in all panels. The right $y$-axis is identical in all panels. However, it should be noted that the left $y$-axis differs in all panels.

methanotrophs may have environmental significance as natural gas consists of $\sim 1.8-5.1 \%$ (vol\%) $\mathrm{C}_{2} \mathrm{H}_{6}$ (Demirbas, 2010). Further, $\mathrm{C}_{2} \mathrm{H}_{6} \mathrm{O}$ is a significant product of fermentation by primary fermenters during anoxic decomposition of organic compounds (Reith et al., 2002). The results also demonstrate that electrons derived from the oxidation of $\mathrm{NH}_{3}$ to $\mathrm{NO}_{2}{ }^{-}$ were effectively utilized by nitrite and nitric oxide reductases in M. album strain BG8, which represents yet another pathway for methanotrophic $\mathrm{N}_{2} \mathrm{O}$ production that is not directly dependent on single-carbon metabolism, provided that the methane monooxygenase can access endogenous reductant (Dalton, 1977; King and Schnell, 1994; Stein and Klotz, 2011).

Instantaneous $\mathrm{O}_{2}$ consumption and $\mathrm{N}_{2} \mathrm{O}$ production measurements (Figures 2-4) provide strong support that catabolism of $\mathrm{C}_{1}-\mathrm{C}_{2}$ substrates and ammonia is directly coupled to $\mathrm{NO}_{2}{ }^{-}$reduction under hypoxia in $M$. album strain BG8. Some aerobic methanotrophs ferment $\mathrm{CH}_{4}$ and excrete organic compounds such as citrate, acetate, succinate, and lactate (Kalyuzhnaya et al., 2013). Some studies also suggest that methanotrophs only support denitrification within $\mathrm{CH}_{4}$-fed consortia by supplying these excreted organics to denitrifying bacteria, since methanotrophs were thought incapable of denitrification by themselves (Costa et al., 2000; Knowles, 2005; Liu et al., 2014). Although M. album strain BG8 may excrete organic compounds under hypoxia when provided with $\mathrm{CH}_{4}$, the ability of $\mathrm{CH}_{3} \mathrm{OH}, \mathrm{CH}_{2} \mathrm{O}, \mathrm{HCO}_{2} \mathrm{H}, \mathrm{C}_{2} \mathrm{H}_{6}, \mathrm{C}_{2} \mathrm{H}_{6} \mathrm{O}$, or $\mathrm{NH}_{3}$ oxidation to support denitrification unequivocally demonstrates the linkage between methanotroph-specific enzymology and denitrifying activity within a single organism.

\section{Transcription of Predicted Denitrification Genes, nirS and norB1, Increased in Response to $\mathrm{NO}_{2}-$ but not Hypoxia}

The expression of a nirS homolog in an aerobic methanotroph has been investigated so far only in the $\mathrm{NO}_{3}^{-}$respiring M. denitrificans FJG1 (Kits et al., 2015). Interestingly, the genome of $M$. denitrificans FJG1 encodes both the copper-containing (nirK) and cytochrome $\mathrm{cd}_{1}$ containing (nirS) nitrite reductases and only the steady state mRNA levels of nirK increased in 


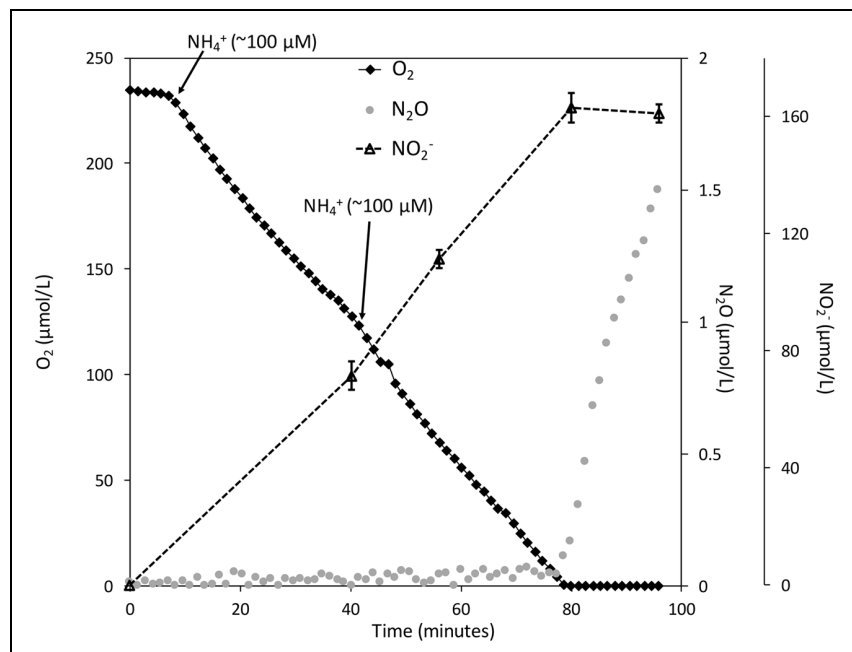

FIGURE 4 | The coupling of $\mathrm{NH}_{3}$ oxidation to $\mathrm{NO}_{2}^{-}$reduction in Methylomicrobium album strain BG8 under hypoxia. Experiments were performed in a closed $10 \mathrm{~mL}$ micro-respiratory chamber outfitted with an $\mathrm{O}_{2}$ and $\mathrm{N}_{2} \mathrm{O}$ microsensor and logged with Sensor Trace Basic software. $\mathrm{O}_{2}$ (black diamonds), $\mathrm{N}_{2} \mathrm{O}$ (gray circles), $\mathrm{NO}_{2}{ }^{-}$(black dashed triangles). Cells of M. album strain BG8 were grown and harvested as described in the materials and methods and resuspended in nitrogen free mineral salts medium. Arrows mark the addition of $\mathrm{NH}_{4}+(100 \mu \mathrm{M})$ to the closed micro-respiratory chamber. Traces $\left(\mathrm{O}_{2}+\mathrm{N}_{2} \mathrm{O}\right)$ are single representatives of reproducible results from cultures grown on different days. $\mathrm{NO}_{2}^{-}$was measured using a colorimetric method as described in the Section "Materials and Methods" and data points represent the mean $\pm \mathrm{SD}$ for three technical replicates.

this strain in response to simultaneous $\mathrm{O}_{2}$ limitation and $\mathrm{NO}_{3}{ }^{-}$ availability (Kits et al., 2015). In the case of M. album strain BG8, which only possesses a nirS homolog, we showed that the abundance of this nirS transcript responded positively to $\mathrm{NO}_{2}{ }^{-}$treatment but not to $\mathrm{O}_{2}$ limitation. This suggests that $\mathrm{NO}_{2}{ }^{-}$availability alone elicits the expression of nirS, even though hypoxia was required for $\mathrm{NO}_{2}{ }^{-}$reduction to occur.

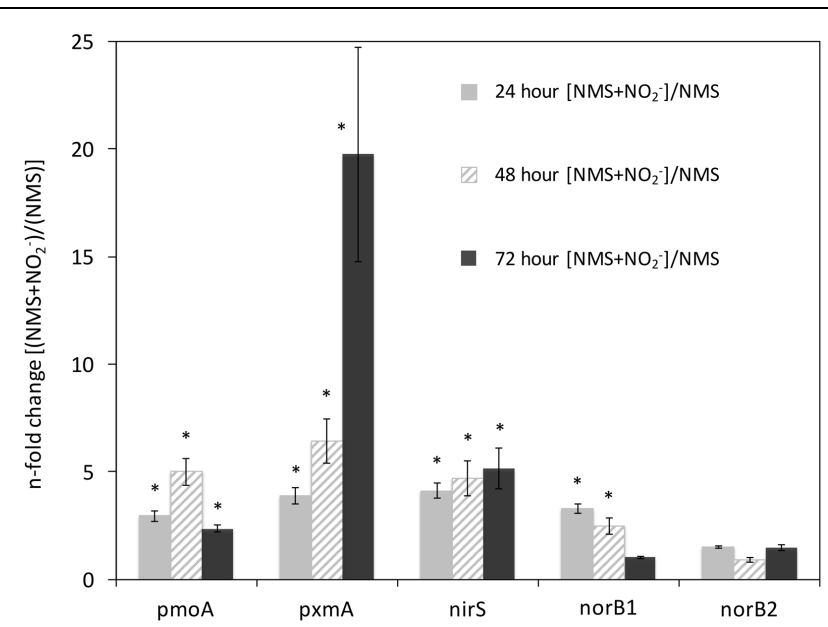

FIGURE 5 | Expression of pmoA, pxmA, nirS, norB1, and norB2 in Methylomicrobium album strain BG8 cultivated in NMS or NMS media amended with $1 \mathrm{mM} \mathrm{NaNO}$. Total RNA was extracted from

Methylomicrobium album strain BG8 at 24, 48, and $72 \mathrm{~h}$ of growth (see Figure 1) from three separate cultures, converted to cDNA, and the abundance of $p m o A$, pxmA, nirS, norB1, and norB2 transcripts was determined using quantitative PCR. The transcript abundance of each gene of interest was normalized to that of $16 \mathrm{~s}$ rRNA. The $\mathrm{n}$-fold change in transcript abundance of the $\mathrm{NO}_{2}{ }^{-}$amended $\left(1 \mathrm{mM} \mathrm{NaNO}_{2}\right) \mathrm{NMS}$ cultures relative to the unamended NMS cultures at $24 \mathrm{~h}$ of growth (light gray), $48 \mathrm{~h}$ of growth (diagonal white/gray), and at $72 \mathrm{~h}$ of growth (black). Error bars represent the SD calculated for triplicate GPCR reactions performed on each of the three biological replicates for each treatment. The $(*)$ above the bars designates a statistical significance $(P<0.05)$ as determined by $t$-test between NMS only and $\mathrm{NMS}+\mathrm{NO}_{2}{ }^{-}$for each time point.

The cytochrome $c$ dependent nitric oxide reductase (nor $B)$ is widely found in the genomes of aerobic methanotrophs (Stein and Klotz, 2011). This may in part be due to the need to detoxify $\mathrm{NO}$ that is produced during aerobic ammonia oxidation by reducing it to $\mathrm{N}_{2} \mathrm{O}$ (Sutka et al., 2003). The expression

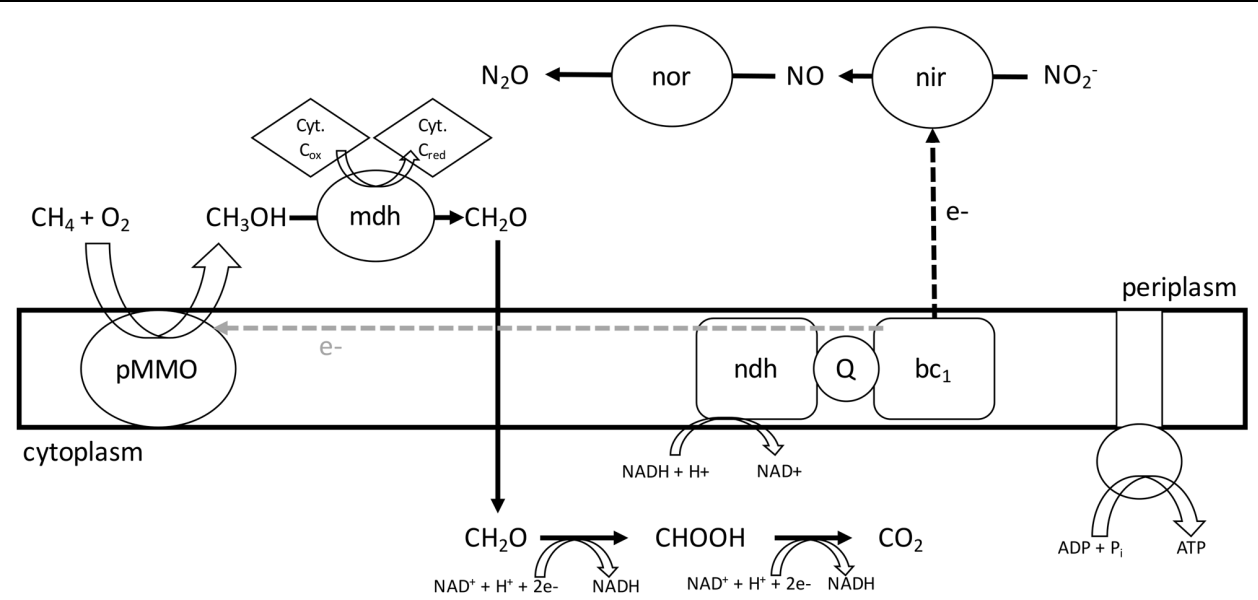

FIGURE 6 | Proposed model for $\mathrm{NO}_{2}^{-}$respiration and central metabolism in Methylomicrobium album strain BG8. During hypoxia, $M$. album strain BG8 utilizes electrons from aerobic $\mathrm{CH}_{4}$ oxidation to respire $\mathrm{NO}_{2}^{-}$. Abbreviations: $\mathrm{pMMO}$, particulate methane monooxygenase; mdh, methanol dehydrogenase; Cyt, cytochrome; nor, nitric oxide reductase; nir, nitrite reductase; ndh, NAD(P)H dehydrogenase complex; $\mathrm{Q}$, coenzyme $\mathrm{Q}$; bc 1 , cytochrome bc ${ }_{1}$ complex. 
of norB in Methylococcus capsulatus strain Bath increased 4.8fold after treatment with $0.5 \mathrm{mM}$ sodium nitroprusside, a NO releasing compound (Campbell et al., 2011). It is possible that the NorB protein is involved in detoxification of $\mathrm{NO}$ during $\mathrm{NH}_{3}$ oxidation in $M$. capsulatus strain Bath, since the genome lacks a dissimilatory nitrite reductase. More recently, it was demonstrated in $M$. fumariolicum strain SolV that transcription of nor $B$ was upregulated during $\mathrm{O}_{2}$ limitation during chemostat growth (Khadem et al., 2012a); however, it is unknown whether M. fumariolicum strain SolV can consume $\mathrm{NO}_{2}{ }^{-}$or NO. The transcription of norB in $M$. denitrificans FJG1 increased 2.8fold in response to $\mathrm{NO}_{3}{ }^{-}$and hypoxia (Kits et al., 2015). While the genome of $M$. album strain BG8 encodes two copies of the nor $B$ gene, only one copy (norB1) is followed by nor $C$ - the essential cytochrome $c$-containing subunit (Mesa et al., 2002). Although some organisms like Cupriavidus necator possess two independent functional nitric oxide reductases (Cramm et al., 1997), the present work illustrates that expression of only norB1 in $M$. album strain BG8 is responsive to $\mathrm{NO}_{2}{ }^{-}$treatment. Although the function of NorB may differ between $M$. album strain BG8 and M. capsulatus strain Bath, both bacteria show a similar transcriptional response of nor $B$ genes to $\mathrm{NO}_{2}{ }^{-}$ (Campbell et al., 2011).

\section{Transcript Abundance of pxmA Significantly Increased in Response to both $\mathrm{NO}_{2}{ }^{-}$and Hypoxia}

Genomes of some aerobic methanotrophs belonging to the phylum Gammaproteobacteria have been shown to encode a sequence divergent CuMMO protein complex, pXMO (Tavormina et al., 2011). The function and substrate of the putative pXMO protein encoded by the pxm operon remains unknown. Previous studies on the pxm operon have shown that it is expressed at low levels during growth in Methylomonas sp. strain LW13 as well as in freshwater peat bog and creek sediment (Tavormina et al., 2011). Metagenomic sequencing of the SIPlabeled active community in an oilsands tailings pond revealed that pxmA sequences were present in the active methanotroph community (Saidi-Mehrabad et al., 2013). Analysis of the transcriptome of $M$. denitrificans FJG1 revealed that steady state mRNA levels of the pxmABC operon increased $\sim 10$-fold in response to denitrifying conditions (Kits et al., 2015).

We now demonstrate that expression of pxmA in $M$. album strain BG8 is significantly increased in response to both $\mathrm{NO}_{2}{ }^{-}$ and hypoxia. We did not observe any increase in the expression of pxmA in $\mathrm{O}_{2}$ limited NMS-only cultures where denitrification was

\section{References}

Bedard, C., and Knowles, R. (1989). Physiology, biochemistry, and specific inhibitors of ch4, nh4+, and co oxidation by methanotrophs and nitrifiers. Microbiol. Rev. 53, 68-84.

Bodelier, P., and Laanbroek, H. (2004). Nitrogen as a regulatory factor of methane oxidation in soils and sediments. FEMS Microbiol. Ecol. 47, 265-277. doi: 10.1016/S0168-6496(03)00304-0

Bodelier, P. L. E., Roslev, P., Henckel, T., and Frenzel, P. (2000). Stimulation by ammonium-based fertilizers of methane oxidation not occurring, suggesting that hypoxia alone is not sufficient to illicit an increase in the steady state mRNA levels. This study adds further support to the observation that expression of $p x m A$ is responsive to denitrifying conditions. However, it must be noted that at $72 \mathrm{~h}$ in the $\mathrm{NO}_{2}{ }^{-}$amended media, absolute transcript abundance of pxmA $\left(1 \times 10^{3}\right.$ copies pxmA/1 $\times 10^{9}$ copies $16 \mathrm{~s}$ rRNA) was three orders of magnitude lower than absolute transcript abundance of $p m o A\left(1 \times 10^{6}\right.$ copies $p x m A / 1 \times 10^{9}$ copies $16 \mathrm{~s}$ rRNA).

\section{Conclusion}

The present study demonstrates that an aerobic methanotroph M. album strain $\mathrm{BG} 8$ - couples the oxidation of $\mathrm{C}_{1}\left(\mathrm{CH}_{4}\right.$, $\left.\mathrm{CH}_{3} \mathrm{OH}, \mathrm{CH}_{2} \mathrm{O}, \mathrm{HCO}_{2} \mathrm{H}\right), \mathrm{C}_{2}\left(\mathrm{C}_{2} \mathrm{H}_{6}, \mathrm{C}_{2} \mathrm{H}_{6} \mathrm{O}\right)$, and inorganic $\left(\mathrm{NH}_{3}\right)$ substrates to $\mathrm{NO}_{2}{ }^{-}$reduction under $\mathrm{O}_{2}$ limitation resulting in release of the potent greenhouse gas $\mathrm{N}_{2} \mathrm{O}$. The ability to couple $\mathrm{C}_{1}, \mathrm{C}_{2}$, and inorganic energy sources to $\mathrm{O}_{2}$ respiration and denitrification gives $M$. album strain BG8 considerable metabolic flexibility. We propose a model for methane driven denitrification in M. album strain BG8 (Figure 6). This discovery has implications for the environmental role of methanotrophic bacteria in the global nitrogen cycle in both $\mathrm{N}_{2} \mathrm{O}$ emissions and $\mathrm{N}$-loss. Comparing the genome and physiology of the $\mathrm{NO}_{2}{ }^{-}$ respiring $M$. album strain $\mathrm{BG} 8$ to $\mathrm{NO}_{3}{ }^{-}$respiring $M$. denitrificans FJG1 suggests that the inability of $M$. album strain BG8 to reduce $\mathrm{NO}_{3}{ }^{-}$to $\mathrm{N}_{2} \mathrm{O}$ is likely due to the absence of a dissimilatory nitrate reductase in the genome, but that expression of predicted denitrification genes, nirS and norB1, enable this aerobic methanotroph to respire $\mathrm{NO}_{2}{ }^{-}$.

\section{Acknowledgments}

This work was supported by a grant to LS from the Natural Sciences and Engineering Research Council of Canada (RGPIN2014-03745) and fellowship support to KK from Alberta Innovates Technology Futures.

\section{Supplementary Material}

The Supplementary Material for this article can be found online at: http://journal.frontiersin.org/article/10.3389/fmicb. 2015.01072

in soil around rice roots. Nature 403, 421-424. doi: 10.1038/350 00193

Bodelier, P. L. E., and Steenbergh, A. K. (2014). Interactions between methane and the nitrogen cycle in light of climate change. Curr. Opin. Environ. Sustain. 9-10, 26-36. doi: 10.1016/j.cosust.2014.07.004

Bollmann, A., French, E., and Laanbroek, H. J. (2011). Isolation, cultivation, and characterization of ammonia-oxidizing bacteria and archaea adapted to low ammonium concentrations. Methods Enzymol. 486(Pt a), 55-88. doi: 10.1016/B978-0-12-381294-0.0 0003-1 
Cammack, R., Joannou, C. L., Cui, X. Y., Martinez, C. T., Maraj, S. R., and Hughes, M. N. (1999). Nitrite and nitrosyl compounds in food preservation. Biochim. Biophys. Acta 1411, 475-488. doi: 10.1016/S0005-2728(99) 00033-X

Campbell, M. A., Nyerges, G., Kozlowski, J. A., Poret-Peterson, A. T., Stein, L. Y., and Klotz, M. G. (2011). Model of the molecular basis for hydroxylamine oxidation and nitrous oxide production in methanotrophic bacteria. FEMS Microbiol. Lett. 322, 82-89. doi: 10.1111/j.1574-6968.2011. 02340.x

Costa, C., Dijkema, C., Friedrich, M., Garcia-Encina, P., Fernandez-Polanco, F., and Stams, A. J. M. (2000). Denitrification with methane as electron donor in oxygen-limited bioreactors. Appl. Microbiol. Biotechnol. 53, 754-762. doi: $10.1007 / \mathrm{s} 002530000337$

Cramm, R., Siddiqui, R. A., and Friedrich, B. (1997). Two isofunctional nitric oxide reductases in Alcaligenes eutrophus H16. J. Bacteriol. 179, 6769-6777.

Dalton, H. (1977). Ammonia oxidation by methane oxidizing bacterium Methylococcus-Capsulatus strain bath. Arch. Microbiol. 114, 273-279. doi: 10.1038/ismej.2008.71

Dalton, H. (1980). Oxidation of hydrocarbons by methane monooxygenases from a variety of microbes. Advan. Appl. Microbiol. 26, 71-87. doi: 10.1016/S00652164(08)70330-7

Dam, B., Dam, S., Blom, J., and Liesack, W. (2013). Genome analysis coupled with physiological studies reveals a diverse nitrogen metabolism in Methylocystis sp. Strain SC2. PLoS ONE 8:e74767. doi: 10.1371/journal.pone. 0074767

Demirbas, A. (2010). Methane gas hydrate. Methane Gas Hydrate 1-186.

Dunfield, P., and Knowles, R. (1995). Kinetics of inhibition of methane oxidation by nitrate, nitrite, and ammonium in a humisol. Appl. Environ. Microbiol. 61, 3129-3135.

Holmes, A. J., Costello, A., Lidstrom, M. E., and Murrell, J. C. (1995). Evidence that particulate methane monooxygenase and ammonia monooxygenase may be evolutionarily related. FEMS Microbiol. Lett. 132, 203-208. doi: 10.1111/j.15746968.1995.tb07834.x

Kalyuzhnaya, M. G., Yang, S., Rozova, O. N., Smalley, N. E., Clubb, J., Lamb, A., et al. (2013). Highly efficient methane biocatalysis revealed in a methanotrophic bacterium. Nat. Commun. 4:2785. doi: 10.1038/ncomms3785

Khadem, A. F., Pol, A., Wieczorek, A. S., Jetten, M. S. M., and Op den Camp, H. J. M. (2012a). Metabolic regulation of "Ca. Methylacidiphilum fumariolicum" soIV cells grown under different nitrogen and oxygen limitations. Front. Microbiol. 3:266. doi: 10.3389/fmicb.2012.00266

Khadem, A. F., Wieczorek, A. S., Pol, A., Vuilleumier, S., Harhangi, H. R., Dunfield, P. F., et al. (2012b). Draft genome sequence of the volcano-inhabiting thermoacidophilic methanotroph Methylacidiphilum fumariolicum strain SoLV. J. Bacteriol. 194, 3729-3730. doi: 10.1128/JB. 00501-12

King, G. M., and Schnell, S. (1994). Ammonium and nitrite inhibition of methane oxidation by methylobacter-albus bg8 and methylosinus-trichosporium ob3b at low methane concentrations. Appl. Environ. Microbiol. 60, 3508-3513.

Kits, K. D., Kalyuzhnaya, M. G., Klotz, M. G., Jetten, M. S. M., Op den Camp, H. J. M., Vuilleumier, S., et al. (2013). Genome sequence of the obligate gammaproteobacterial methanotroph Methylomicrobium album strain BG8. Genome Announc. 1:e0017013. doi: 10.1128/genomeA. 00170-13

Kits, K. D., Klotz, M. G., and Stein, L. Y. (2015). Methane oxidation coupled to nitrate reduction under hypoxia by the Gammaproteobacterium Methylomonas denitrificans, sp. nov. type strain FJG1. Environ. Microbiol. 17, 3219-3232. doi: $10.1111 / 1462-2920.12772$

Knowles, R. (2005). Denitrifiers associated with methanotrophs and their potential impact on the nitrogen cycle. Ecol. Eng. 24, 441-446. doi: 10.1016/j.ecoleng.2005.01.001

Kozlowski, J. A., Price, J., and Stein, L. Y. (2014). Revision of N2O-producing pathways in the ammonia-oxidizing bacterium Nitrosomonas europaea ATCC 19718. Appl. Environ. Microbiol. 80, 4930-4935. doi: 10.1128/AEM. 01061-14

Liu, J., Sun, F., Wang, L., Ju, X., Wu, W., and Chen, Y. (2014). Molecular characterization of a microbial consortium involved in methane oxidation coupled to denitrification under micro-aerobic conditions. Microb. Biotechnol. 7, 64-76. doi: 10.1111/1751-7915.12097

Mesa, S., Velasco, L., Manzanera, M. E., Delgado, M. J., and Bedmar, E. J. (2002). Characterization of the norCBQD genes, encoding nitric oxide reductase, in the nitrogen fixing bacterium Bradyrhizobium japonicum. Microbiology 148, 3553-3560. doi: 10.1099/00221287-148-11-3553

Mountfort, D. O. (1990). Oxidation of aromatic alcohols by purified methanol dehydrogenase from Methylosinus-Trichosporium. J. Bacteriol. 172, 36903694.

Muyzer, G., de Waal, E. C., and Uitterlinden, A. G. (1993). Profiling of complex microbial populations by denaturing gradient gel electrophoresis analysis of polymerase chain reaction-amplified genes coding for 16s rRna. Appl. Environ. Microbiol. 59, 695-700.

Nyerges, G., Han, S., and Stein, L. Y. (2010). Effects of ammonium and nitrite on growth and competitive fitness of cultivated methanotrophic bacteria. Appl. Environ. Microbiol. 76, 5648-5651. doi: 10.1128/AEM.00747-10

Poret-Peterson, A. T., Graham, J. E., Gulledge, J., and Klotz, M. G. (2008). Transcription of nitrification genes by the methane-oxidizing bacterium, Methylococcus capsulatus strain bath. ISME J. 2, 1213-1220. doi: 10.1038/ismej.2008.71

Reith, F., Drake, H. L., and Kusel, K. (2002). Anaerobic activities of bacteria and fungi in moderately acidic conifer and deciduous leaf litter. FEMS Microbiol. Ecol. 41, 27-35. doi: 10.1111/j.1574-6941.2002.tb00963.x

Richardson, D. J., Berks, B. C., Russell, D. A., Spiro, S., and Taylor, C. J. (2001). Functional, biochemical and genetic diversity of prokaryotic nitrate reductases. Cell. Mol. Life Sci. 58, 165-178. doi: 10.1007/PL00000845

Saidi-Mehrabad, A., He, Z., Tamas, I., Sharp, C. E., Brady, A. L., Rochman, F. F., et al. (2013). Methanotrophic bacteria in oilsands tailings ponds of northern Alberta. ISME J. 7, 908-921. doi: 10.1038/ismej.2012.163

Stein, L. Y. (2011). "Heterotrophic nitrification and nitrifier denitrification," in Nitrification, eds. B. B. Ward, D. J. Arp, and M. G. Klotz (Washington, DC: ASM Press). 95-114.

Stein, L. Y., Bringel, F., DiSpirito, A. A., Han, S., Jetten, M. S. M., Kalyuzhnaya, M. G., et al. (2011). Genome sequence of the methanotrophic alphaproteobacterium Methylocystis sp strain rockwell (ATCC 49242). J. Bacteriol. 193, 2668-2669. doi: 10.1128/JB.00278-11

Stein, L. Y., and Klotz, M. G. (2011). Nitrifying and denitrifying pathways of methanotrophic bacteria. Biochem. Soc. Trans. 39, 1826-1831. doi: 10.1042/BST20110712

Stieglmeier, M., Mooshammer, M., Kitzler, B., Wanek, W., ZechmeisterBoltenstern, S., Richter, A., et al. (2014). Aerobic nitrous oxide production through $\mathrm{N}$-nitrosating hybrid formation in ammonia-oxidizing archaea. ISME J. 8, 1135-1146. doi: 10.1038/ismej.2013.220

Sutka, R. L., Ostrom, N. E., Ostrom, P. H., Gandhi, H., and Breznak, J. A. (2003). Nitrogen isotopomer site preference of N2O produced by Nitrosomonas europaea and Methylococcus capsulatus bath. Rapid Commun. Mass Spectrom. 17, 738-745. doi: $10.1002 / \mathrm{rcm} .968$

Svenning, M. M., Hestnes, A. G., Wartiainen, I., Stein, L. Y., Klotz, M. G., Kalyuzhnaya, M. G., et al. (2011). Genome sequence of the arctic methanotroph Methylobacter tundripaludum SV96. J. Bacteriol. 193, 6418-6419. doi: 10.1128/JB.05380-11

Tavormina, P. L., Orphan, V. J., Kalyuzhnaya, M. G., Jetten, M. S. M., and Klotz, M. G. (2011). A novel family of functional operons encoding methane/ammonia monooxygenase-related proteins in gammaproteobacterial methanotrophs. Environ. Microbiol. Rep. 3, 91-100. doi: 10.1111/j.17582229.2010.00192.x

Vuilleumier, S., Khmelenina, V. N., Bringel, F., Reshetnikov, A. S., Lajus, A., Mangenot, S., et al. (2012). Genome sequence of the haloalkaliphilic methanotrophic bacterium Methylomicrobium alcaliphilum 20Z. J. Bacteriol. 194, 551-552. doi: 10.1128/JB.06392-11

Wei, W., Isobe, K., Nishizawa, T., Zhu, L., Shiratori, Y., Ohte, N., et al (2015). Higher diversity and abundance of denitrifying microorganisms in environments than considered previously. ISME J. 9, 1954-1965. doi: 10.1038/ismej.2015.9

Whittenbury, R., Phillips, K. C., and Wilkinson, J. F. (1970). Enrichment, isolation and some properties of methane-utilizing bacteria. J. Gen. Microbiol. 61, 205218. doi: 10.1099/00221287-61-2-205 
Yoshinari, T. (1985). Nitrite and nitrous oxide production by Methylosinus trichosporium. Can. J. Microbiol. 31, 139-144. doi: 10.1139/m85-027

Conflict of Interest Statement: The authors declare that the research was conducted in the absence of any commercial or financial relationships that could be construed as a potential conflict of interest.
Copyright (c) 2015 Kits, Campbell, Rosana and Stein. This is an open-access article distributed under the terms of the Creative Commons Attribution License (CC BY).

The use, distribution or reproduction in other forums is permitted, provided the original author(s) or licensor are credited and that the original publication in this journal is cited, in accordance with accepted academic practice. No use, distribution or reproduction is permitted which does not comply with these terms. 